\title{
Thermal comfort properties of cool-touch nylon and common nylon knitted fabrics with different fibre fineness and cross-section
}

DOI: 10.35530/IT.072.02.20209

YANG YANG

LIU XIN

YU XIN

ZHANG PEIHUA

WANG XUNGAI

\section{ABSTRACT - REZUMAT \\ Thermal comfort properties of cool-touch nylon and common nylon knitted fabrics with different fibre fineness and cross-section}

Cool-touch nylon multi-filament yarns with good heat transfer performance are widely used in the development of knitted fabrics for summer and sports clothing. However, the physical properties of cool-touch nylon fibres, and the effect of fineness and cross-section on comfort-related properties of their knitted fabrics are still not well understood. In this study, the physical properties of cool-touch nylon fibres and common nylon fibres, and comfort properties of knitted fabrics from both fibre types were measured and compared. It was found that cool-touch nylon fibres have better moisture absorption, but slightly lower crystallinity than common nylon fibres. Regarding the fibre fineness and cross-section of cool-touch nylon and common nylon, knitted fabrics showed a similar dependence on thermal comfort properties. Cool-touch nylon fabrics had increased wicking capacity, thermal transfer, and cooling properties, but poorer drying performance and moisture permeability compared to common nylon fabrics. It was concluded that using nylon multi-filament yarns made up of finer filaments and cool touch filaments is an effective way to develop thermal-wet comfort knitted fabrics for summer and sports clothing applications.

Keywords: cool-touch nylon, physical performance, cross-section, fibre diameter, thermal comfort

Proprietățile de confort termic ale tricoturilor din nailon cool-touch și din nailon comun, cu finețe și secțiuni transversale diferite ale fibrelor

Firele multifilamentare din nailon cool-touch, cu performanțe ridicate de transfer de căldură, sunt utilizate pe scară largă în dezvoltarea tricoturilor pentru îmbrăcămintea pentru sezonul cald și îmbrăcămintea sport. Cu toate acestea, proprietățile fizice ale fibrelor de nailon cool-touch și influența fineții și a secțiunii transversale a acestor fibre asupra proprietăților de confort ale tricoturilor nu sunt încă bine înțelese. În acest studiu, au fost măsurate și comparate proprietățile fizice ale fibrelor de nailon cool-touch și ale fibrelor din nailon comun, precum și proprietățile de confort ale tricoturilor din ambele tipuri de fibre. S-a constatat că fibrele de nailon cool-touch au o absorbție a umidității mai ridicată, dar cristalinitate ușor mai scăzută decât fibrele din nailon comun. Din punct de vedere al fineții și secțiunii transversale a fibrelor de nailon cool-touch și nailon comun, tricoturile prezintă o dependență similară de proprietățile de confort termic. Tricoturile din nailon cool-touch au o capacitate ridicată de absorbție, transfer termic și proprietăți de răcire, dar performante mai scăzute de uscare și permeabilitate la umiditate comparativ cu tricoturile din nailon comun. S-a ajuns la concluzia că utilizarea firelor multifilamentare din nailon formate din filamente mai fine și filamente cool-touch este o modalitate eficientă de a dezvolta tricoturi cu proprietăți de confort termic pentru îmbrăcămintea pentru sezonul cald și îmbrăcămintea sport.

Cuvinte-cheie: nailon cool-touch, performanță fizică, secțiune transversală, diametrul fibrei, confort termic

\section{INTRODUCTION}

Nylons are high-performance materials with attractive physical and mechanical properties. They have moisture sensitive performance (official regain, 4.5\%) [1], and their knitted fabrics offer good thermo-physiological comfort as well as high elasticity [2]. Thus, nylon knitted fabrics are widely used in the development of summer and sports clothing.

Thermal comfort plays an important role in determining clothing comfort and affects human physical and psychological well-being [3]. Cool-touch feeling has received much attention for summer clothing as well as sports and outdoor apparel for healthy living [4]. To improve the cool-touch feeling of nylon fabrics, many effective methods have been reported, such as metal sputtering [5], nano-coating [6] on nylon fabrics, and producing cool-touch nylon fibres by adding nanoparticles to nylon matrix [7]. Jade-containing cooltouch nylon fibres [8] that were prepared by mixing jade nanoparticles into thermoplastic melt and extruding the melt to produce filaments, have attracted increasing attention in the development of knitted fabrics for sports clothing. Thermal comfort is mainly determined by air permeability, moisture management properties, and heat transfer performance. In a warm and humid environment, high air permeability increases comfort, and high thermal conduction of fabric is beneficial for cooling body when excessive 
heat is produced [9]. Excellent moisture absorption and transfer by a fabric have the benefit of maintaining a dry and comfortable microclimate near skin after excessive sweating. A large amount of heat also could be absorbed and diffused during the moisture transfer process, which promotes the cooling function of clothing [10].

Factors that affect the thermal comfort properties of fabrics can be basically categorized into fibre, yarn, and fabric properties [11]. In terms of fibre properties, hydrophilicity, thermal conductivity, and the crosssection of a fibre influence heat and moisture transfer capacity $[4,12]$. The hydrophilicity of fibre greatly influences its wicking behaviour [13], and the moisture sorption of fibre material in a fabric is associated with cool-touch feeling when skin contacts the fabric [14]. The fineness of fibres greatly affects the thermal comfort property of fabrics [15], and thermal comfort is enhanced with the decrease of fibre diameter. The composition and fibre cross-section affected the cooling efficiency of fabrics, especially, knitted fabric containing polyester yarns with grooved surface showed good cooling capacity [16]. Furthermore, the thickness and porosity of fabric [17] affect the thermal comfort properties of fabrics, as increasing the fabric thickness improves thermal insulation and higher porosity benefits breathability.

However, few studies have been reported on the properties of cool-touch nylon fibres containing jade nanoparticles and their fabrics. This work aims to extend the scope of thermal comfort research on cool-touch nylon fibres and their knitted fabrics by conducting a comparative study between cool-touch nylon and common nylon. In this work, physical properties of cool-touch nylon and common nylon fibres, breathability, moisture transfer, thermo-physiological and cooling characteristics of their knitted fabrics, were investigated and compared. Meanwhile, the effects of fibre fineness and cross-section on the thermal comfort properties of knitted fabrics were analysed.

\section{MATERIALS AND METHODS}

\section{Materials}

We selected four cool-touch nylon filaments with varied fibre fineness and cross-section but same denier (D) (70D), and four common nylon filaments with same specifications. All filaments were produced by Taihua New Material Co., China. Information on these filaments is shown in table 1. The surface morphology and cross-section profile of cool-touch nylon fibres and common nylon fibres are shown in figure 1. With increasing filament numbers $(F)$ within the multifilament yarns, the average fibre diameter (d) of cooltouch nylon filament and common filament is reduced.

Knitted fabric samples made from these nylon filament yarns were produced on a Double rib circular knitting machine (E22). During production, all machine parameters for these samples were kept the same, and each fabric had an identical $1 \times 1$ interlock structure. Because single fine nylon filament is not suitable for this knitting machine, two filament yarns were combined to form a twisted yarn. The specification of eight knitted fabric samples are shown in table 2.

\begin{tabular}{|c|c|c|c|c|c|c|c|c|}
\hline \multicolumn{9}{|c|}{ THE SPECIFICATION OF COOL-TOUCH NYLON FILAMENT (CPA) AND COMMON NYLON FILAMENT (PA) } \\
\hline Characteristics & \multicolumn{4}{|c|}{ CPA } & \multicolumn{4}{|c|}{ PA } \\
\hline Cross-section & \multicolumn{2}{|c|}{ Crisscross $(+)$} & \multicolumn{2}{|c|}{ Circle $(\mathrm{O})$} & \multicolumn{2}{|c|}{ Crisscross $(+)$} & \multicolumn{2}{|c|}{ Circle $(\mathrm{O})$} \\
\hline Number of filaments in yarn & 34 & 68 & 48 & 68 & 34 & 68 & 48 & 68 \\
\hline
\end{tabular}

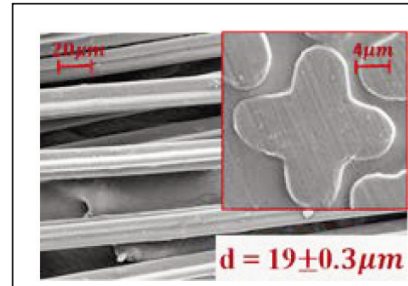

CPA 70D $/ 34 \mathrm{~F}+$

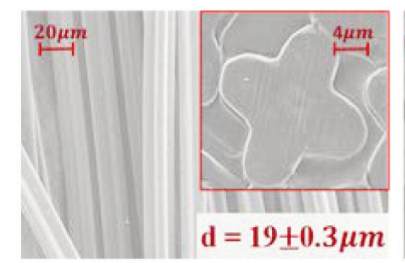

PA 70D/34F +

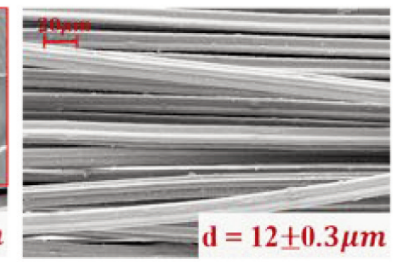

CPA 70D $/ 68 F+$

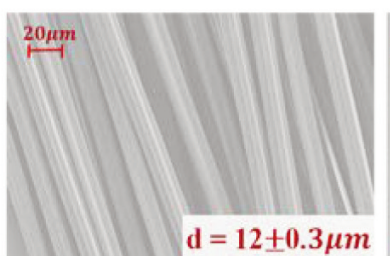

PA 70D/68F +

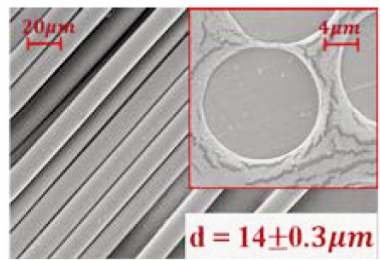

CPA 70D/48F O

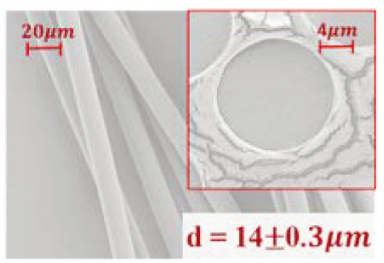

PA 70D/48F O

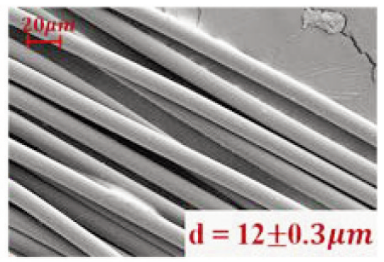

CPA 70D/64F O

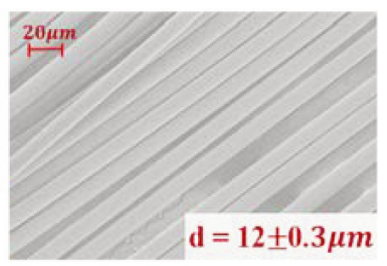

PA 70D/64F O

Fig. 1. Fibber surface and cross-section morphology of nylon filaments 


\begin{tabular}{|l|c|c|c|c|c|c|c|c|}
\hline \multicolumn{8}{|c|}{ THE SPECIFICATION OF FABRIC SAMPLES PREPARED BY NYLON TWISTED YARNS } \\
\hline \multirow{2}{*}{ Characteristics } & $\mathbf{7 0 D / 3 4 F +}$ & \multicolumn{2}{c|}{ 70D/68F + } & \multicolumn{2}{c|}{ 70D/48F O } & \multicolumn{2}{c|}{ 70D/68F O } \\
\cline { 2 - 9 } & CPA & PA & CPA & PA & CPA & PA & \multicolumn{1}{c|}{ CPA } & PA \\
\hline Weight $\left(\mathrm{g} / \mathrm{m}^{2}\right)$ & 221 & 218 & 221 & 225 & 218 & 220 & 221 & 223 \\
\hline Wale density $(/ 5 \mathrm{~cm})$ & 68 & 68 & 70 & 68 & 70 & 70 & 68 & 68 \\
\hline Course density $(/ 5 \mathrm{~cm})$ & 70 & 72 & 72 & 74 & 72 & 72 & 72 & 72 \\
\hline Thickness $(\mathrm{mm})$ & 0.900 & 0.883 & 0.813 & 0.826 & 0.840 & 0.840 & 0.834 & 0.836 \\
\hline
\end{tabular}

\section{Methods}

Thermal performance of both cool-touch nylon and common nylon fibres was measured with a Differential Scanning Calorimeter (TA Q200, TA Instruments, USA). The crystallinity of fibres was calculated by ratio of heat associated with melting (fusion) of fibres against the heat of fusion for a $100 \%$ crystalline nylon sample [18].

Moisture regain is defined as the percentage of moisture present in a textile material of oven dry weight. The drying weight was obtained by drying fibre samples for 4 hours at a specific temperature of $105 \pm 3^{\circ} \mathrm{C}$. The moisture was absorbed by a sample in the standard atmosphere $\left(20 \pm 2^{\circ} \mathrm{C}\right.$ and $65 \pm 2 \%$ relative humidity) for over 48 hours after drying.

Wicking height of fabric samples was measured through a vertical wicking test method. The fabric strips $(2.5 \mathrm{~cm} \times 30 \mathrm{~cm})$ were suspended vertically in such a way that their lower ends were immersed in a reservoir with distilled water. The scale adjacent to the stripes was used to measure the wicking height in six intervals (each of five minutes) for 30 minutes.

Drying rate of fabric samples was tested with a RF4008HP Drying Rate Tester (heated-plate method, REFOND Equipment Co., China) according to AATCC MT 201 standard. The fabric test area was 15 $\times 15 \mathrm{~cm}^{2}$.

Thermal-physiological properties of fabric were evaluated through a Sweat Guarded Hotplate apparatus (YG606, Ningbo Textile Instrument Factory, China), according to ASTM D1776/D1776M-16-2008 standard. The q-max value of fabric samples was tested by the KES-F7 (Kato Tech Co., Japan) in the standard environment to evaluate the transient cool-touch performance.

Dynamic cooling property was tested by measuring the thermal properties of wet fabric [19]. The test was performed by YG606 II Thermal Resistance Tester (Ningbo Textile Instrument Factory, China) that was refitted by adding a program to control heating power $(22.0 \mathrm{~W})$. This setup contains a testing board with some high precision temperature sensors to record the temperature changes of test board surface. Since the inner surface of fabric contacts the surface of test board, the temperature of fabric inner surface with time was measured in the testing process. The conditioned samples were soaked in water with the set weight of $20 \mathrm{~g}$.
One-way ANOVA analysis (SPSS v.22.0, IBM Corp.) was performed to determine whether the varied fibre diameter and cross-section significantly affect comfort-related properties. The symbols "**" and "*” in the results represent significant differences at $99 \%$ and $95 \%$ confidence intervals respectively.

\section{RESULTS AND DISCUSSION}

\section{Properties of filaments}

Thermal properties

Cool-touch nylon fibres show lower melting enthalpy and crystallinity than those of common nylon fibres (table 3), indicating that the introduction of jade nanoparticles inhibited the crystallization of nylon fibres. Coarser cool-touch nylon and common nylon fibres 70D/48FO and 70D/34F+ show lower melting enthalpy and crystallinity than finer fibres $70 \mathrm{D} / 68 \mathrm{FO}$ and $70 \mathrm{D} / 68 \mathrm{~F}+$ respectively. The melting enthalpy and crystallinity of fibres with crisscross sections are higher than fibres with circular sections. The crystallinity of nylon fibres is also dependent on the conditions during the fibre extrusion process, which affect fibre fineness and cross-section.

Table 3

\begin{tabular}{|c|c|c|c|c|}
\hline \multicolumn{3}{|c|}{$\begin{array}{l}\text { MELTING ENTHALPY AND CRYSTALLINITY OF } \\
\text { COOL-TOUCH AND COMMON NYLON FIBRES }\end{array}$} \\
\hline \multirow{2}{*}{ Specification } & \multicolumn{2}{|c|}{$\begin{array}{c}\text { Melting enthalpy } \\
\text { (J/g) }\end{array}$} & \multicolumn{2}{c|}{$\begin{array}{c}\text { Crystallinity } \\
\text { (\%) }\end{array}$} \\
\cline { 2 - 5 } & CPA & PA & CPA & PA \\
\hline 70D/68F O & 40.92 & 42.78 & 17.79 & 18.60 \\
\hline $70 \mathrm{D} / 48 \mathrm{~F} \mathrm{O}$ & 36.34 & 39.1 & 15.80 & 17.00 \\
\hline 70D/68F + & 45.93 & 52.21 & 19.97 & 22.70 \\
\hline $70 \mathrm{D} / 34 \mathrm{~F}+$ & 42.22 & 47.47 & 18.36 & 20.64 \\
\hline
\end{tabular}

Moisture regain is an important parameter to evaluate the moisture absorption capacity of a material. As shown in table 4, cool-touch nylon filaments have higher moisture regain than common nylon filaments with the same specifications, indicating the addition of jade nanoparticles increases the moisture absorption capacity of fibres. This is mainly caused by good moisture absorption of nano-jade [20] and the amorphous region of cool-touch fibres. Furthermore, moisture regain values of $70 \mathrm{D} / 68 \mathrm{~F}+$ and $70 \mathrm{D} / 68 \mathrm{~F}$ O filaments are higher than those of $70 \mathrm{D} / 34 \mathrm{~F}+$ and 70D/48F $O$ filaments respectively, and moisture 


\begin{tabular}{|c|c|c|c|c|c|}
\hline \multicolumn{6}{|c|}{ THE RATE OF MOISTURE REGAIN OF COOL-TOUCH NYLON AND COMMON NYLON FILAMENTS } \\
\hline Property & Filaments & $\mathbf{7 0 D / 3 4 F +}$ & $\mathbf{7 0 D / 6 8 F}+$ & $\mathbf{7 0 D / 4 8 F}$ O & 70D/68F O \\
\hline \multirow{2}{*}{ Moisture regain (\%) } & CPA & $5.46(0.14)$ & $6.00(0.19)$ & $5.30(0.25)$ & $5.59(0.21)$ \\
\cline { 2 - 6 } & PA & $4.56(0.31)$ & $4.87(0.13)$ & $4.33(0.17)$ & $4.70(0.22)$ \\
\hline
\end{tabular}

Note. Data in brackets is the standard deviation of the mean.

regain of $70 \mathrm{D} / 68 \mathrm{~F}+$ filaments are also higher than $70 \mathrm{D} / 68 \mathrm{~F} O$ filaments. These results demonstrate that finer fibres and crisscross fibres are beneficial for moisture absorption due to the increase of fibre surface area.

\section{Properties of knitted fabrics \\ Wicking height}

The wicking heights of cool-touch nylon and common nylon fabric samples along wale and course directions in 30 minutes are shown in figure 2. It shows that wicking height of cool-touch nylon knitted fabrics is higher than common nylon knitted fabrics with the same yarn specifications. This is due to higher moisture and water absorption abilities of cool-touch fibres. Fibre cross-section and fineness have similar effects on wicking height of cool-touch nylon fabrics and common nylon fabrics. Higher wicking height is presented by common and cool-touch knitted fabrics prepared by crisscross section fibres, indicating crisscross section is conducive to improve vertical wicking capacity for fabrics. It is known that imbibition occurs mainly due to capillary forces, and capillary force arises from the geometry of the pores in the textiles [21]. The crisscross section nylon fibres have grooves on their surface, forming more capillaries inside the fabric which improve the wicking ability.

For the samples with circular cross-section, wale and course wicking heights of fabrics made of finer fibres are higher than those of the fabrics made of coarser fibre. This is because the capillary force of fabrics made up of circular cross-section filaments is generated by spaces between the fibres. With the increase of fibre quantity (decrease of fibre diameter) in a fixed space, there is an increase in the capillaries formed by voids between fibres. Therefore, increasing the fibre quantity or decreasing fibre diameter of yarn promotes the wicking ability of the resultant fabric. However, for the samples with crisscross section, fabrics made of finer fibres have lower wicking height. Even though the liquid movement firstly begins in the smaller capillaries under capillary pressure, it then continues to fill the larger capillaries [22]. Overlarge or undersized capillary radius decreases wicking ability of fabrics [23]. The capillary radius of the finer crisscross section fibres is too small to form effective capillaries. Meanwhile, the increased specific surface area benefits the moisture absorption but prohibits the moisture transfer. Whereas, the coarser fibres have relatively large capillary radius, which forms more effective capillaries, and are more conducive to the wicking effect of fabrics.

Drying property

As shown in figure 3, cool-touch nylon fabrics have slightly lower drying rate than common nylon fabrics made up of yarns with same specifications. This is mainly because better moisture absorption of cooltouch nylon fabrics inhibits water evaporation, which leads to poorer drying performance. It is also known that the higher drying speed is exhibited by samples made up of circular cross-section fibres in the group of fabrics made up of $70 \mathrm{D} / 68 \mathrm{~F}$ filaments over crisscross section fibre groups. The reason may be attributed to the tiny grooves of fibres within the crisscross section leading to more water being adsorbed. As a result, moisture transferring and evaporating
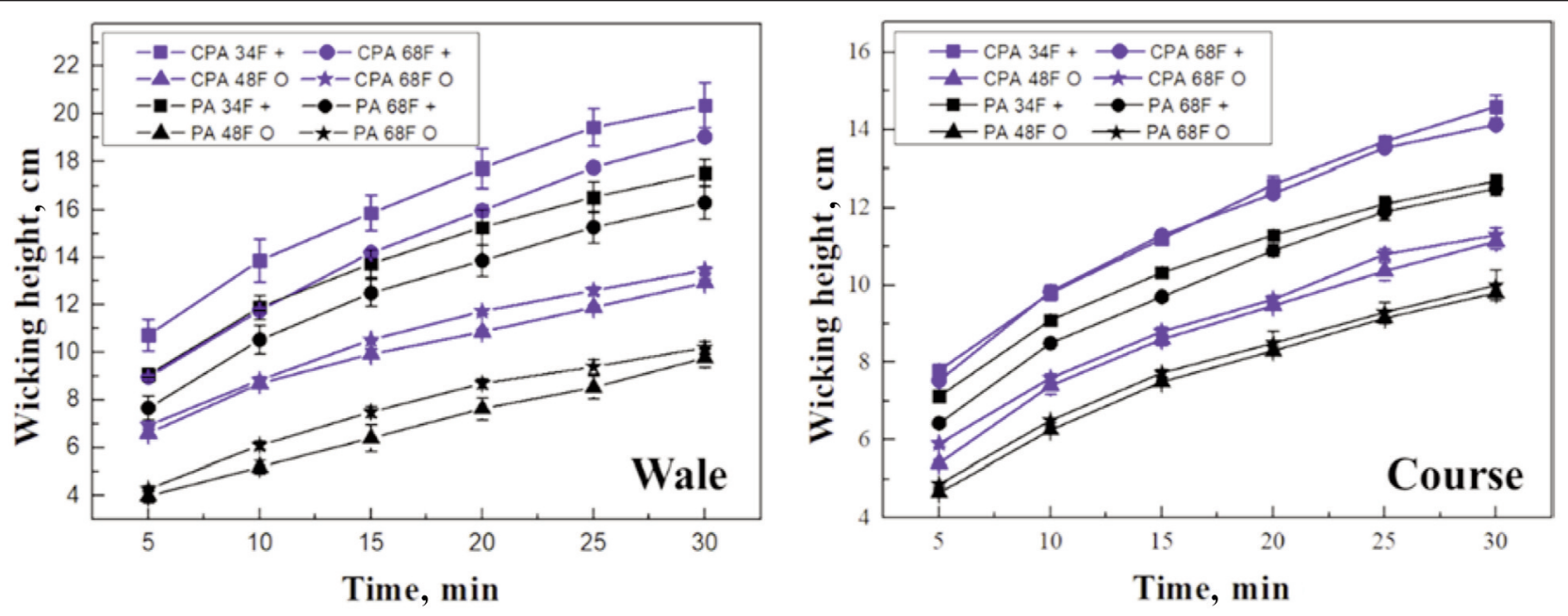

Fig. 2. Wicking height with time of cool-touch nylon and common nylon knitted fabrics 
towards outside are confined. Drying speed of cooltouch nylon and common nylon samples with circular cross-section increased successively when fibre diameter decreases, e.g. 70D/48F O and 70D/68F O. This is because more capillaries are formed within the fabric. Thus, there are more channels for water diffusion and evaporation. However, there is no significant difference in drying speed between samples with crisscross section, e.g. 70D/34F + and 70D/68F +. Thus, tiny grooves on finer fibres have a negative effect on drying performance.

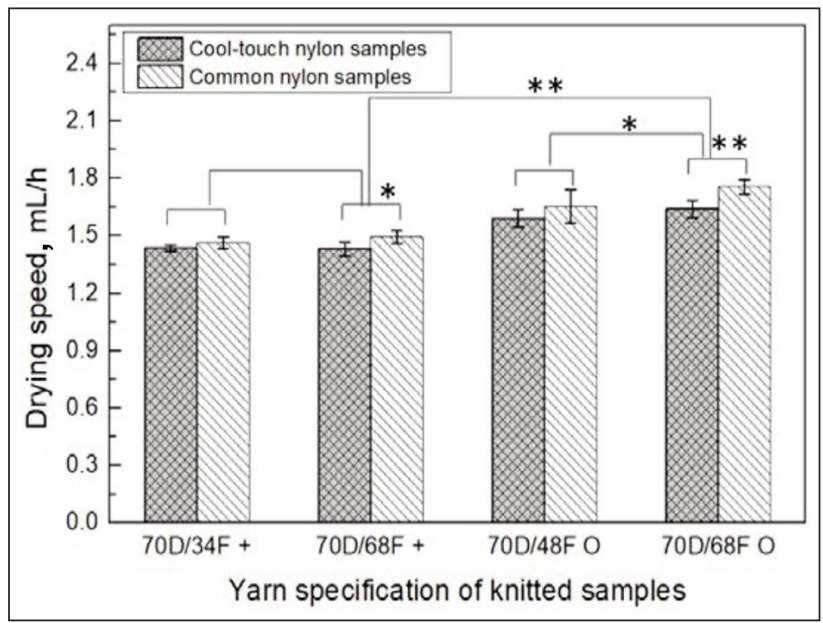

Fig. 3. The drying speed of cool-touch nylon and common nylon knitted samples

\section{Thermal-physiological property}

Testing thermal resistance and water vapour resistance can characterize the thermal-physiological properties of fabrics. As shown in figure 4, there are highly significant differences of thermal resistance and water vapour resistance between cool-touch nylon and common nylon fabric samples. The thermal resistance of cool-touch nylon samples is lower than common nylon samples. Conversely, the water vapour resistance of cool-touch nylon samples is slightly higher than common nylon samples. This illustrates that cool-touch nylon fabrics have better heat transfer performance due to higher thermal conductivity of jade. However, better moisture absorption of cool-touch nylon fibres inhibits moisture transfer, resulting poorer moisture permeability. It also can be found from figure 4 that differences of thermal resistance and water vapour resistance between samples with varied fineness, e.g. 70D/48F $\mathrm{O}$ and 70D/68 F O, are significant. For samples with similar circular section, thermal resistance of samples made of finer fibres is lower than samples made of coarser fibres, whereas, the water vapour resistance of these samples shows an opposite variation trend. This illustrates that better heat conduction is exhibited by fabrics made of finer fibres. Because thermal conductivity coefficient of fibres is higher than air, the lower fineness of fibres increases the contact area between fibres, which promotes thermal conduction by fibres. However, with the decrease of fineness, the moisture absorption of fibres increases, which has a negative effect on moisture permeability. For samples with similar crisscross section, there is no significant difference in water vapour resistance between fabrics with different fibre fineness. This could be due to the interaction of gaps in fabric and gaps of fibre moisture absorption. However, thermal resistance of samples made up of finer fibres is higher than samples made up of coarser fibres. The opposite trend is shown in samples with circular section. Although decreasing the diameter of crisscross section fibres improves the contact area, more still air remained in finer crisscross section fibres decreases the heat conduction. Fibber cross-section has significant effect on heat transfer performance of fabrics. The thermal resistance of samples made of crisscross section fibres, e.g. $70 \mathrm{D} / 68 \mathrm{~F}+$, is higher than samples made of circular cross-section fibres, e.g. 70D/68F O. Irregularity of fibre cross-section hinders heat conduction, because the irregular fibre cross-section
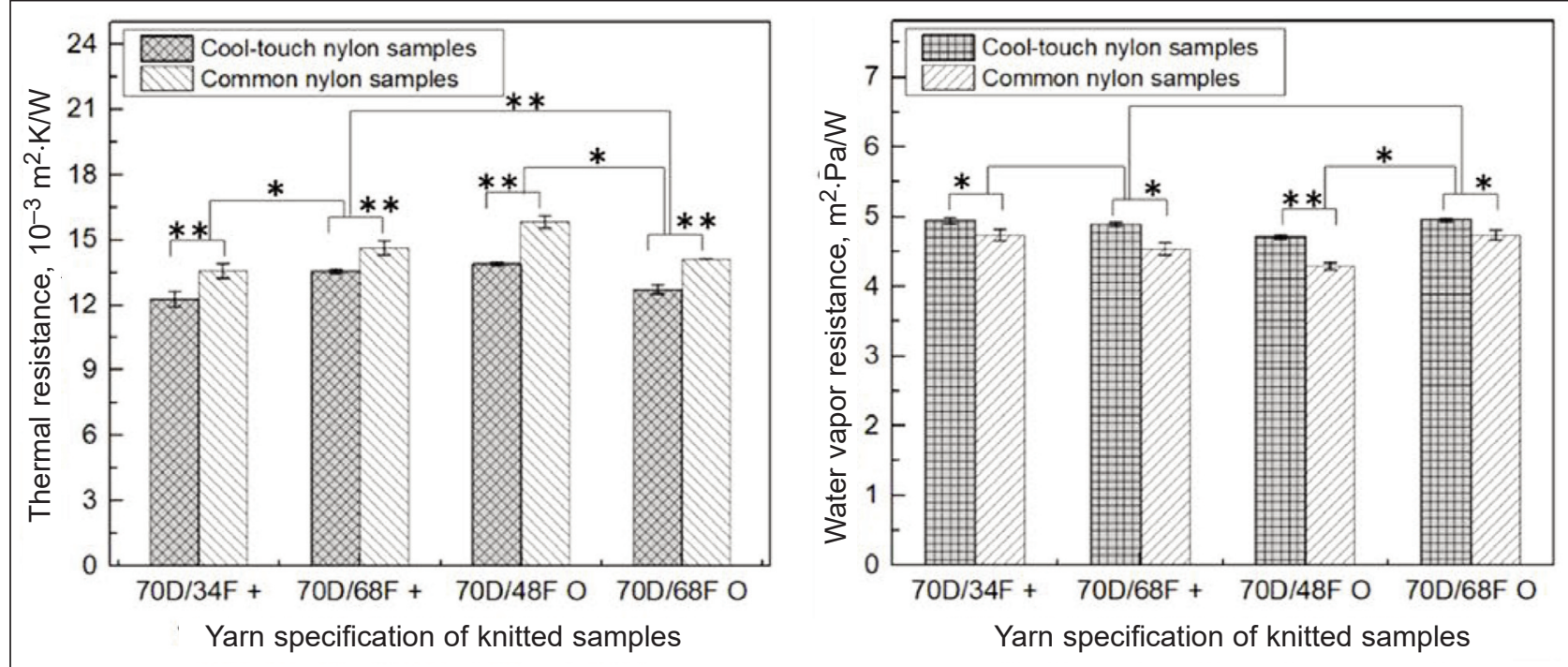

Fig. 4. Thermal resistance and water vapour resistance of cool-touch and common nylon knitted samples 
increases the amount of still air contained in fabrics, and reduces the thermal conductivity of the fabric. However, due to the irregularity of fibre cross-section, more water vapour transfer channels are formed, moisture absorption then increases. Thus, there is no significant difference of water vapour resistance between samples 70D/68F + and 70D/68F O.

Transient cool touch performance

With the increase of q-max value, the cool-touch performance is enhanced [24]. The surface morphology and the thermal conductivity of the fabric material are the main factors affecting warm/cool feeling. The q-max values of the cool-touch nylon samples are significantly higher than common nylon samples (figure 5). This suggests that the usage of cool-touch nylon filaments benefits fabrics' transient cool touch performance due to their enhanced thermal conductivity. The q-max values of samples with finer fibres are less than samples with coarser fibres, e.g. samples $70 \mathrm{D} / 34 \mathrm{~F}+$ and $70 \mathrm{D} / 68 \mathrm{~F}+$, samples $70 \mathrm{D} / 48 \mathrm{~F} \mathrm{O}$ and $70 \mathrm{D} / 68 \mathrm{~F} O$ (figure 5). The main reason is that the q-max value is the maximum heat flux at the moment the body skin contacts fabric, which depends on the thermal transfer capacity of the fabric contacting the skin surface. Coarser fibres are more favourable to

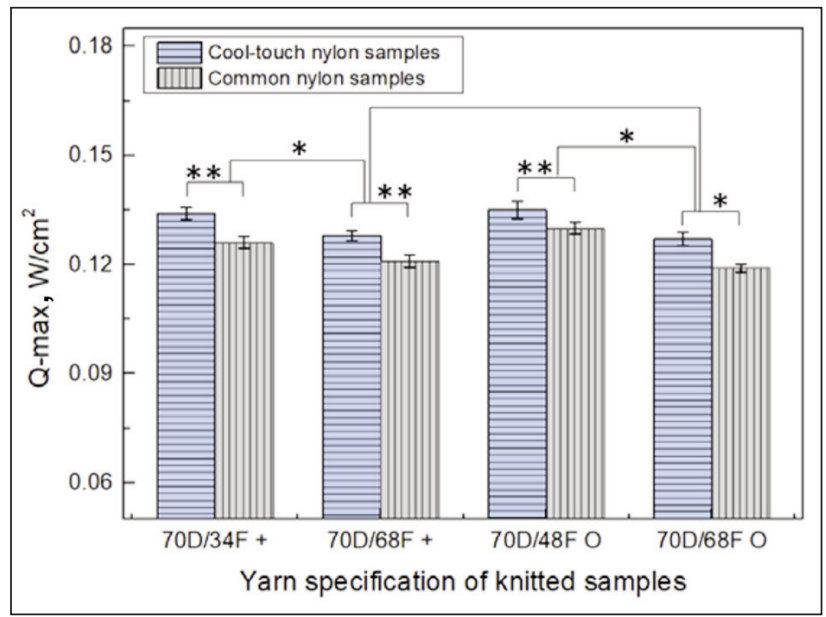

Fig. 5. The q-max values of cool-touch nylon and common nylon knitted samples heat transfer through fibres and improve maximum heat flux when body skin contacts fabric.

\section{Dynamic cooling property}

The heat and moisture transfer of clothing is a dynamic process after absorbing moisture. The excellent heat conduction and moisture diffusion benefit the improvement of cooling performance. The dynamic cooling function after sweating could be estimated by measuring the heating property of wet fabrics. With the decreasing temperature of samples in a given heating time, the dynamic cooling property is better [19]. As shown in figure 6, a, wet cool-touch nylon samples and common nylon samples have similar heating property, and their heating temperature with time is significantly lower than the test board. This illustrates that wet fabric significantly promotes the cooling function due to moisture transfer and evaporation. It is also shown that there are two stages in the heating process of wet samples. In the first stage, the temperature increases slightly. However, the temperature increases significantly in the second stage. At the beginning, the moisture evaporation takes away much heat and moisture, which improves the heat loss of fabric. More gaps in wet fabric are filled with water rather than still air, which also increases the heat conductivity of fabric. As a result, temperature increases slowly at this stage. Subsequently, the evaporation rate and heat conductivity decrease with decreasing water content, resulting in a rapid increase of temperature.

Figure $6, b$ shows the temperature difference between wet samples and test board with heating time. It is an important parameter for evaluating the cooling function of fabrics used for summer and sports clothing [19]. The maximum temperature difference is in the range $7^{\circ} \mathrm{C}$ to $7.88^{\circ} \mathrm{C}$. This illustrates that moisture evaporation obviously improves cooling effect.

In order to investigate the cooling efficiency, the average cooling rate was calculated (figure $6, c$ ). With the increasing average cooling rate, the fabric has better cooling performance. The average cooling rates of cool-touch nylon samples are higher than common

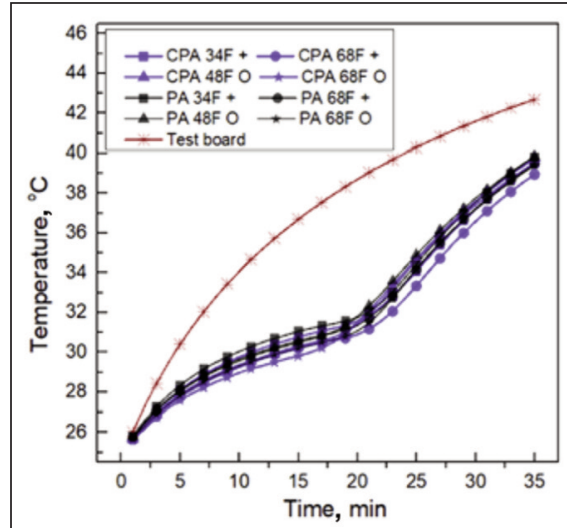

a

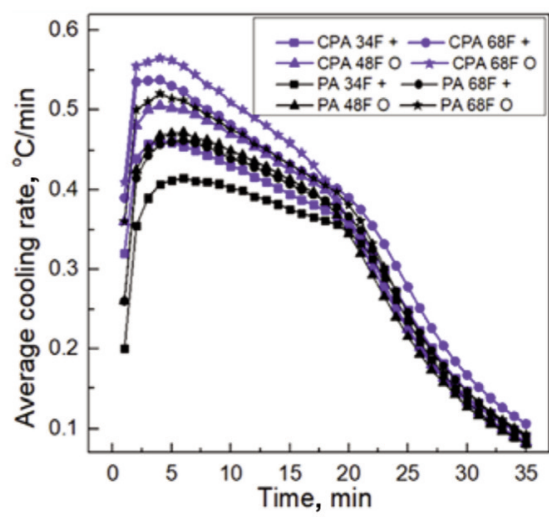

b

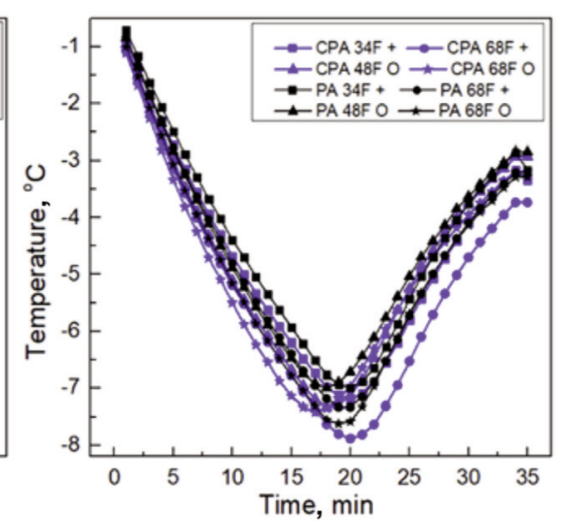

$c$

Fig. 6. Dynamic cooling performance of wet samples: $a$ - the temperature variation heating time; $b-$ the temperature difference between wet samples and test board with time; $c$ - the average cooling rate with time 
nylon samples with the same specification respectively. It demonstrates that cool-touch nylon knitted fabrics have better cooling performance. This is explained by better heat transfer ability of cool-touch nylon fabrics than common nylon fabrics.

Furthermore, samples made up of finer fibres have better cooling property than samples made up of coarser fibres. Meanwhile, higher cooling rate is exhibited by samples made up of circular cross-section fibres in the group of samples made up of yarns with 68F. Fibbers with crisscross section have no positive effect on the improvement of the dynamic cooling property of knitted fabrics prepared by nylon filaments used in this work. Thus, to improve the dynamic cooling property of nylon knitted fabrics used for summer and sports clothing, using filaments made of finer fibres and cool touch filaments with circular cross-section is an effective way.

\section{CONCLUSION}

In this work, the physical properties of cool-touch nylon filaments and common nylon filaments, and thermal comfort properties of their knitted fabrics with $1 \times 1$ interlock structure were investigated. Meanwhile, the effects of fineness and fibre cross-section of common and cool-touch nylon filaments on comfort properties of their knitted fabrics were examined. It was found that cool-touch nylon fibres had better moisture absorption, but slightly lower crystallinity than common nylon fibres. Cool-touch nylon fabrics had better wicking capacity, thermal transfer and cooling properties, but poorer drying performance and moisture permeability than common nylon fabrics. Fibre fineness and cross-section had similar effects on thermal comfort properties of cool-touch nylon and common nylon knitted fabrics. Finer fibres were conducive to improve drying performance, thermal transfer and dynamic cooling properties of their knitted fabrics. Nylon yarns with fine crisscross section filaments had no positive effect on thermal-wet comfort ability of their fabrics. Therefore, using nylon multi-filament yarns with finer filaments and cool touch filaments provides an effective way to develop thermal-wet comfort knitted fabrics used for summer or sports clothing.

\section{ACKNOWLEDGEMENTS}

This work was supported by National Key R\&D Program of China under Grant 2017YFB0309100, "the Fundamental Research Funds for the Central Universities under Grant CUSF-DH-D-2018024", and China Scholarship Council under Grant 201806630035.

\section{REFERENCES}

[1] Jia, N., Fraenkel, H., Kagan, V., Effects of moisture conditioning methods on mechanical properties of injection molded nylon 6, In: Journal of Reinforced Plastics and Composites, 2004, 23, 7, 729-737

[2] Kumar, B., Kumar, M., Parthiban, M., Ramachandran, T., Effect of Pique and Honeycomb Structures on Moisture Management Properties of Eri Silk Knitted Fabrics, In: Journal of Natural Fibers, 2019, 16, 1-10

[3] Pan, Y., Hsieh, C., Lou, C., Wang, C., Lin, Z., Chen, Y., Lin, J., Elastic knits with different structures composed by using wrapped yarns: Function and comfort evaluations, In: Fibers and Polymers, 2017, 18, 9, 1816-1824

[4] Park, J., Yoo, H., Hong, K., Kim, E., Knitted fabric properties influencing coolness to the touch and the relationship between subjective and objective coolness measurements, In: Textile Research Journal, 2018, 88, 17, 1931-1942

[5] Han, H., Kim, J., A study on the thermal and physical properties of nylon fabric treated by metal sputtering (Al, Cu, Ni), In: Textile Research Journal, 2018, 88, 21, 2397-2414.

[6] Rezaei, F., Maleknia, L., Valipour, P., Chizari, G., Improvement properties of nylon fabric by corona pre-treatment and nano coating, In: The Journal of The Textile Institute, 2016, 107, 10, 1223-1231

[7] Ahn, K., Kim, K., Kim, M., Kim, J., Fabrication of silicon carbonitride-covered boron nitride/Nylon 6, 6 composite for enhanced thermal conductivity by melt process, In: Ceramics International, 2015, 41, 2, 2187-2195

[8] Liu, Y., Meng, J., Han, Y., Shan, H., Development of Jade Nylon-Based Fibers and Viscose Blended Yarn, In: Advanced Materials Research, 2011, 332, 2135-2141

[9] Guo, S., Yu, D., Liu, Y., Wang, Z., Zhu, C., Zhang, H., Design and development of cool multifunctional composite high-grade fabrics, In: Applied Mechanics and Materials, 2014, 633, 476-479

[10] Zhou, H., Wang, H., Niu, H., Zeng, C., Zhao, Y., Xu, Z., Fu, S., Lin, T., One-Way Water-Transport Cotton Fabrics with Enhanced Cooling Effect. In: Advanced Materials Interfaces, 2016, 3, 17, 1-6

[11] Jhanji, Y., Gupta, D., Kothari, V., Effect of fibre, yarn and fabric variables on heat and moisture transport properties of plated knit, In: Indian Journal of Fibre \& Textile Research, 2017, 42, 3, 255-263

[12] Jia, T., Wang, Y., Dou, Y., Li, Y., Andrade, M., Wang, R., Fang, S., Li, J., Yu, Z., Qiao, R., Liu, Z., Moisture Sensitive Smart Yarns and Textiles from Self-Balanced Silk Fiber Muscles, In: Advanced Functional Materials, 2019, 29, 18, 1808241

[13] Kumar, B., Das, A., Vertical wicking behavior of knitted fabrics, Fibers and Polymers, 2014, 15, 3, 625-631

[14] Li, Y., Holcombe, B., Dear, R., Enhancement of coolness to the touch by hygroscopic fibers: part II: physical mechanisms, In: Textile Research Journal, 66, 9, 587-594

[15] Gun, A., Dimensional, physical and thermal comfort properties of plain knitted fabrics made from modal viscose yarns having microfibers and conventional fibers, In: Fibers and Polymers, 2011, 12, 2, 258-267

[16] Hesa L., Ursache M., Effect of composition of knitted fabrics on their cooling efficiency at simulated sweating, In: Indian Journal of Fibre \& Textile Research, 2011, 36, 281-284. 
[17] Nazir, M., Shaker, K., Nawab, Y., Fazal, M., Khan, M., Umair, M., Investigating the effect of material and weave design on comfort properties of bilayer-woven fabrics, In: The Journal of the Textile Institute, 2017, 108, 8, 1319-1326

[18] Millot, C., Fillot, L., Lame, O., Sotta, P., Seguela, R., Assessment of polyamide-6 crystallinity by DSC, In: Journal of Thermal Analysis and Calorimetry, 2015, 122, 1, 307-314

[19] Yang, Y., Zhang, W., Zhang, P., Evaluation method for the hygroscopic and cooling function of knitted fabrics, In: Textiles Research Journal, 2019, 89, 23-24, 5024-5040

[20] Cui, S., Zhu, J., Li, B., Wang, S., Liu, Y., Structure and Physical Properties of Jade Fiber, In: Advanced Materials Research, 2012, 441, 767-771

[21] Parada, M., Derome, D., Rossi, R., Carmeliet, J., A review on advanced imaging technologies for the quantification of wicking in textiles, In: Textile Research Journal, 2017, 87, 1, 110-132

[22] Saricam, C., Kalaoğlu, F., Investigation of the wicking and drying behaviour of polyester woven fabrics, In: Fibres \& Textiles in Eastern Europe, 2014, 105, 3, 73-78

[23] Zhang, Y., Wang, H., Zhang, C., Chen, Y., Modeling of capillary flow in shaped polymer fiber bundles, In: Journal of materials science, 2007, 42, 19, 8035-8039

[24] Inoue, T., Nakayama, A., Niwa, M., Relationship between the warm/cool feeling of fabric and the subjective evaluation of the quality of ladies' knitted fabrics, In: International Journal of Clothing Science and Technology, 2010, 22, 1, 7-15

\section{Authors: \\ YANG YANG ${ }^{1}$, YU XIN², WANG XUNGAI ${ }^{2}$, LIU XIN², ZHANG PEIHUA ${ }^{1}$}

1Donhua University, College of Textiles, 2999 North Renmin Road, Songjiang District, 201620, Shanghai, China

2Deakin University, Institute for Frontier Materials, 75 Pigdons Road, Waurn Ponds, 3216, Geelong, Australia

\section{Corresponding authors:}

LIU XIN

e-mail: xin.liu@deakin.edu.au

ZHANG PEIHUA

e-mail:phzh@dhu.edu.cn 